\title{
Growth, single-crystal structure, and magnetic properties of the double molybdate $\mathrm{KYb}\left(\mathrm{MoO}_{4}\right)_{2}$
}

\author{
P. Armand*, C. Reibel, D. Granier, M. Tillard
}

ICGM, CNRS, University of Montpellier, ENSCM, Montpellier, France

*corresponding author

pascale.armand@umontpellier.fr

Phone: +33 (0)4 67143319

ORCID: 0001-8921-5427

\begin{abstract}
Crystals of the rare earth double molybdate $\mathrm{KYb}\left(\mathrm{MoO}_{4}\right)_{2}$ were grown by spontaneous nucleation from a $\mathrm{K}_{2} \mathrm{Mo}_{4} \mathrm{O}_{13}$ flux. The typical crystals were colorless and elongated, welldeveloped plates. The material has been characterized by powder X-ray diffraction (PXRD), energy-dispersive X-ray spectrometry (EDS), and Raman spectroscopy methods. The structural properties have been investigated through single-crystal X-ray diffraction at room temperature. $\mathrm{KYb}\left(\mathrm{MoO}_{4}\right)_{2}$ crystallizes in the orthorhombic symmetry, space group Pbcn (No. 60), $a=5.0395(2), b=18.2821(9), c=7.8635(4) \AA$, and $\mathrm{Z}=4$. A complete ordering of the $\mathrm{Yb}^{3+}$ and $\mathrm{Mo}^{6+}$ cations has been found. The $\mathrm{Yb}^{3+}$ ions are located in distorted $\mathrm{YbO}_{8}$ antiprisms which form chains of edge-sharing, aligned along the $c$-axis while the $\mathrm{Mo}^{6+}$ ions are placed in a slightly deformed tetrahedral environment of oxygen atoms. Double bridge modes of the " $\mathrm{Mo}_{2} \mathrm{O}_{8}$ dimers" have been identified in the unpolarized Raman spectra. The temperature-dependent magnetic susceptibility of $\mathrm{KYb}\left(\mathrm{MoO}_{4}\right)_{2}$ follows a Curie-Weiss law with a Weiss constant of $-52 \mathrm{~K}$.
\end{abstract}

Keywords: A. oxides; B. crystal growth; C. X-ray diffraction; D. crystal structure; D. magnetic properties 


\section{Introduction}

Double molybdates and tungstates $(\mathrm{DMo} / \mathrm{DW})$ of general formula $\mathrm{AT}\left(\mathrm{XO}_{4}\right)_{2}$ with $\mathrm{X}=\mathrm{Mo}^{\mathrm{VI}}$ or $\mathrm{W}^{\mathrm{VI}}$, a monovalent element $\mathrm{A}$ and a trivalent or lanthanide element $\mathrm{T}$, exist with a wide variety of polymorphic forms, mainly tetragonal and orthorhombic, which largely depend on the ratio of the ionic radii $\mathrm{A}^{+} / \mathrm{T}^{3+}[1-6]$. This structural diversity results in several properties such as negative thermal expansion, third-harmonic generation or ionic conduction, and applications in modern technology [7-11]. Special attention has been paid to trigonal DMo and DW due to their simple structure and their ability to undergo ferroelastic phase transitions over wide temperature ranges $[2,11]$. Some DMo and DW phases, such as orthorhombic (Pbna) $\mathrm{KYMo}_{2} \mathrm{O}_{8}$, have potential applications as microchip lasers due to their perfect cleavage in the (100) planes $[2,8,10]$.

The compounds $\mathrm{AT}\left(\mathrm{XO}_{4}\right)_{2}$ have generated some interest as new materials for laser systems because the isostructural substitution of the trivalent element $\mathrm{T}$ by optically active lanthanides $\mathrm{Ln}$ is possible over a wide concentration range, sometimes up to the stoichiometric composition. For example, $\mathrm{KGd}\left(\mathrm{WO}_{4}\right)_{2}$ is well-known as an efficient Raman material that contains an ionic molecular complex that exhibits active oscillations of Stimulated Raman Scattering [12].

Moreover, the lanthanide-based, magnetically concentrated crystals of double tungstates and molybdates are shown to display optical properties such as photon upconversion emission as well as interesting magnetic properties [13, 14]. Single-molecule magnets (SMM) and singleion magnets (SIM) systems based on oxygen coordination polyhedra around $\mathrm{Nd}^{3+}$ and/or $\mathrm{Yb}^{3+}$ lanthanides have been synthesized $[15,16]$.

The present work is part of a study aimed at the synthesis and structural evaluation of the Lnbased magnetically-concentrated double molybdates, $\mathrm{KLn}\left(\mathrm{MoO}_{4}\right)_{2}$. The formation of several 
molybdates of this family has already been reported in the past $[1-3,8,10,15,17-21]$ but very fragmentary information is available for $\mathrm{KYb}\left(\mathrm{MoO}_{4}\right)_{2}[14,19,21]$.

We present here the flux-growth of the orthorhombic phase $\mathrm{KYb}\left(\mathrm{MoO}_{4}\right)_{2}$ and its singlecrystal structure determined at room temperature. The magnetization and hysteresis loops have been measured in a temperature range from 1.8 to $300 \mathrm{~K}$ to study its magnetic behavior.

\section{Experimental}

\subsection{Material preparation}

The starting reagents were commercial Alfa Aesar products $\mathrm{MoO}_{3}(99.95 \%), \mathrm{K}_{2} \mathrm{CO}_{3}(99 \%)$, and $\mathrm{Yb}_{2} \mathrm{O}_{3}(99.9 \%)$, and were used as received. Crystals were obtained using the hightemperature flux growth technique through spontaneous crystallization. The $\mathrm{K}_{2} \mathrm{Mo}_{4} \mathrm{O}_{13}$ flux was previously synthesized via a solid-state reaction at $500{ }^{\circ} \mathrm{C}$ for two weeks, from powders of $\mathrm{K}_{2} \mathrm{CO}_{3}$ alkali carbonate $(31 \mathrm{~g})$ and $\mathrm{MoO}_{3}$ molybdenum oxide $(129 \mathrm{~g})$. A total amount of 20 $\mathrm{g}$ of an intimate mixture of $\mathrm{Yb}_{2} \mathrm{O}_{3}$ and $\mathrm{K}_{2} \mathrm{Mo}_{4} \mathrm{O}_{13}$ in a weight ratio of $10 / 90$ was then placed in a $5 \mathrm{~cm}^{3} \mathrm{Pt}$ crucible and heated in an electrical furnace at $970{ }^{\circ} \mathrm{C}$ in air for 6 hours to ensure the complete dissolution of the solute. Then, the temperature was slowly lowered at a rate of $1 \%$ down to $700{ }^{\circ} \mathrm{C}$ for crystal growth, then the furnace was turned off. Crystals were obtained at the top of the solidified flux from which they were separated by dissolving the flux in water.

\subsection{Material characterization}

The crystallized material was characterized by classical EDX analyses, Raman spectroscopy, and X-ray diffraction. More details on the experimental conditions can be found in a previous paper [22]. Le Bail profile refinement has been performed using the program Jana2006 [23]. 
A stereo microscope with a polarizing filter was used to select a single crystal for X-ray diffraction data collection. Diffracted intensities were measured at room temperature on an Xcalibur CCD diffractometer (Oxford diffraction, Mo $\mathrm{K} \alpha$ radiation) and corrected for Lorentz-polarization effects using CrysAlis software [24]. Absorption correction was applied using the included numerical procedure. The structure was solved and refined using the SHELX programs $[25,26]$ and anisotropic displacement parameters were considered for all atoms. For all atoms, the site occupation factors were freely refined and remain close to their normal values (within $2 \sigma$ limits) indicating the complete filling of the sites and a good agreement of the refined stoichiometry with the analysis of crystals.

Magnetization (M) was measured using a commercial Superconducting Quantum Interference Device (SQUID) MPMS-7XL magnetometer in DC mode. Temperature-dependent magnetization was measured between 1.8 and $300 \mathrm{~K}$ in an intermediate $\mathrm{H}$ field of $5 \mathrm{kOe}(0.5$ Tesla). Magnetic susceptibility $\chi$ was defined as $\mathrm{M} / \mathrm{H}$. The field-dependent magnetization was measured between 1.8 and $300 \mathrm{~K}$ using the same equipment with magnetic fields up to 5 Tesla.

\section{Results and discussion}

\subsection{Flux and crystals characterizations}

The formation of the $\mathrm{K}_{2} \mathrm{Mo}_{4} \mathrm{O}_{13}$ flux in the powder form was characterized by roomtemperature X-ray powder diffraction, Figure 1. It was positively compared with the Powder Diffraction Standards Card Nº0-27-0416 [27]. 


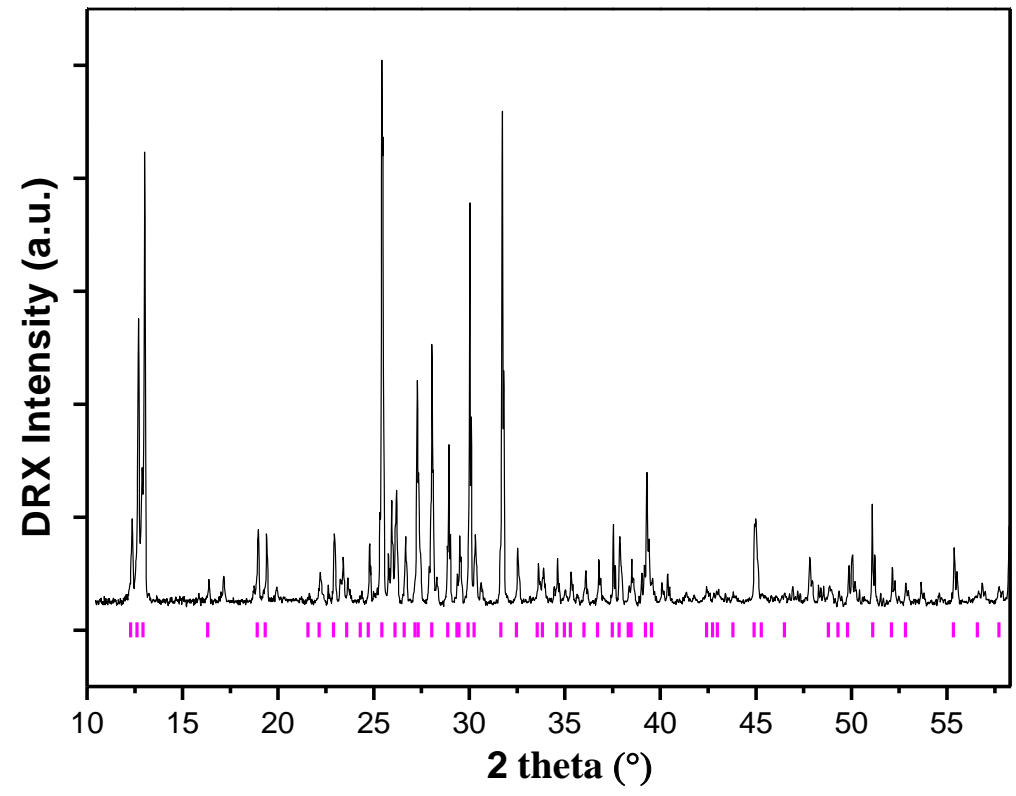

Figure 1. XRD experimental powder pattern $(\lambda=1.5418 \AA)$ of $\mathrm{K}_{2} \mathrm{Mo}_{4} \mathrm{O}_{13}$ indexed with the Bragg positions (pink bars) of the $\mathrm{K}_{2} \mathrm{Mo}_{4} \mathrm{O}_{13}$ PDF card [27].

Spontaneous nucleation yielded sub-millimeter and millimeter-sized plate-shaped crystals, and no post-growth annealing was applied. Figure 2 shows selected as-grown crystals with dimensions up to $6.0 \times 1.2 \times 0.5 \mathrm{~mm}$. The transparent and colorless crystals display good optical quality, they are free of macroscopic inclusions and present sharp edges.

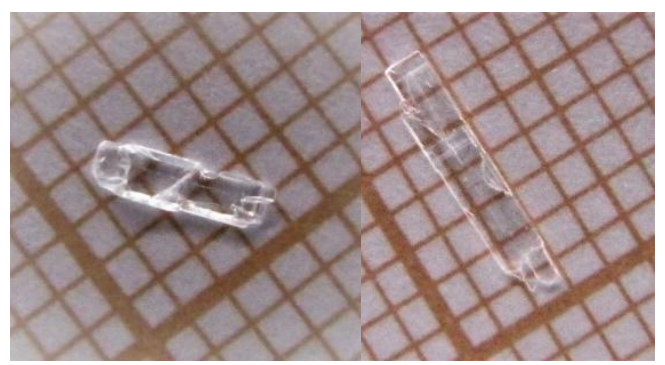

Figure 2. Selected as-grown crystals of $\mathrm{KYb}\left(\mathrm{MoO}_{4}\right)_{2}$ shown on millimeter grid paper. 
The chemical composition was checked by EDX analysis on an as-grown single crystal (not polished sample), and no significant variation in stoichiometry was observed when scanning across the crystal. The elements $\mathrm{K}, \mathrm{Yb}, \mathrm{Mo}$, and $\mathrm{O}$ were found in a molar ratio 7.0(3):10.34(6):17.5(4):65.1(7) which leads to the compound formula $\mathrm{K}_{0.80(5)} \mathrm{Yb}_{1.18(2)} \mathrm{Mo}_{2.00(2)} \mathrm{O}_{7.44(3)}$.

The $\mathrm{Cu} \mathrm{K} \alpha \mathrm{XRD}$ powder pattern registered for a crushed sample in standard conditions at room temperature is given in Figure 3. All the diffraction peaks in the $2 \theta$ range from 5 to $70^{\circ}$ were indexed in agreement with the JCPDS card $n^{\circ}$ 00-050-1762 [28] which announces $\mathrm{KYb}\left(\mathrm{MoO}_{4}\right)_{2}$ to crystallize in the orthorhombic space group $D_{2 h}^{14}(\mathrm{Pbcn})$ with four formula units per unit cell.

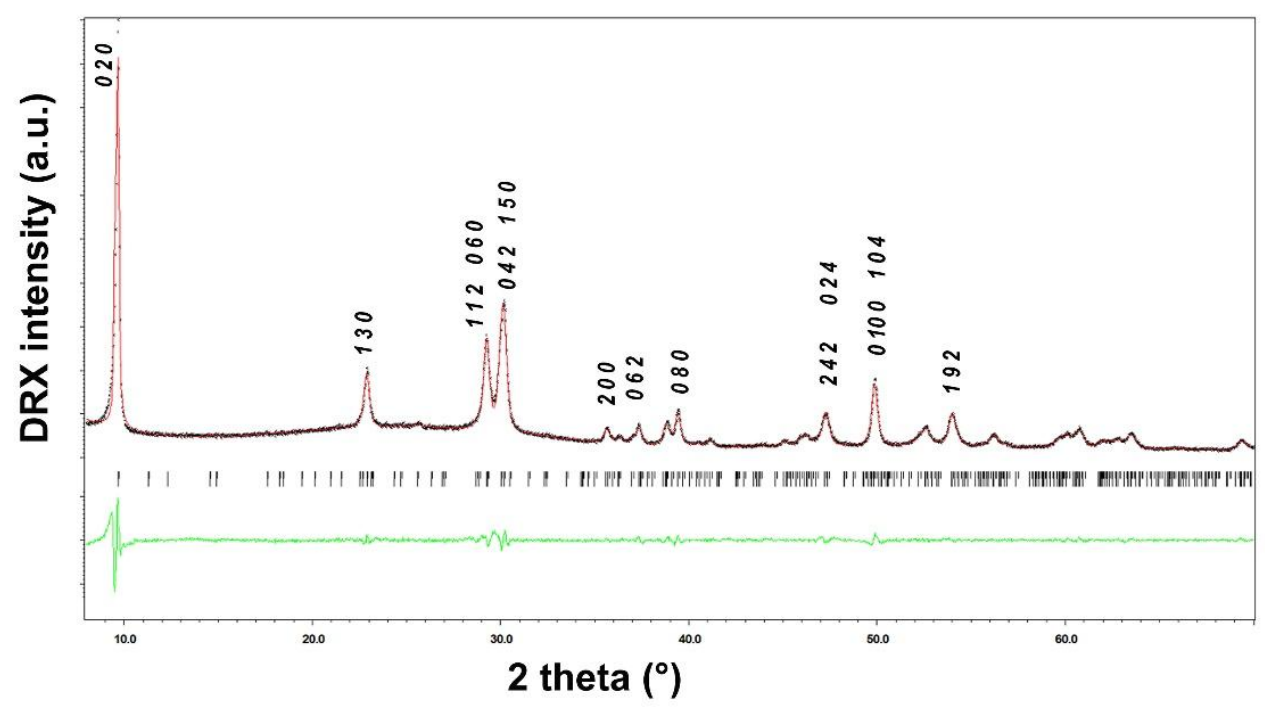

Figure 3. XRD experimental (black data points) powder pattern $(\lambda=1.5418 \AA)$ of $\mathrm{KYb}\left(\mathrm{MoO}_{4}\right)_{2}$, calculated profile (red line) and difference curve (green line). Cell parameters converged to $\mathrm{a}=5.045(2), \mathrm{b}=18.297(4), \mathrm{c}=7.852(2) \AA$ in Le Bail refinement.

These results confirm the formation, under the stated experimental conditions, of the crystallized stoichiometric phase $\mathrm{KYb}\left(\mathrm{MoO}_{4}\right)_{2}$ containing the magnetic ytterbium element in its stable $\mathrm{Yb}^{3+}$ oxidation state. 


\subsection{Single-crystal structure}

The crystal displayed orthorhombic symmetry and the reflections were indexed in a lattice with $a=5.0395(2), \quad b=18.2821(9), \quad c=7.8635(4) \AA$. Since the statistics indicate centrosymmetric and reflections $O k l: k=2 n+1, h O l: l=2 n+1, h k 0: k+k=2 n+1$ were systematically absent from the data set, the space group Pbcn (No. 60) was selected. The structural model found from direct methods includes one Mo and four oxygens at general $8 d$ positions as well as $\mathrm{Yb}$ and $\mathrm{K}$ at special $4 c$ positions with $C_{2}$ local symmetry. This leads to four $\mathrm{KYb}\left(\mathrm{MoO}_{4}\right)_{2}$ units in the orthorhombic cell and leads to assign the $\mathrm{KY}\left(\mathrm{MoO}_{4}\right)_{2}$ structural type [17] to the compound. During the refinement, discrepancies are noted for some reflections, seemingly poorly measured. These problems result from the existence of a parasitic crystallite hanging on the main crystal that affects the measure of intensities in the corresponding domain and consequently the agreement factors values. However, the final structural refinement was carried out to an R1 agreement factor of $5.57 \%$. The main crystal data and structure refinement details are reported in Table 1, while the atomic positions and equivalent displacement parameters are listed in Table 2. The full CIF file with the CSD number 2049313 can be freely obtained from the Cambridge Crystallographic Data Center (CCDC) [29]. 
Table 1. Crystal data, structure refinement, and data collection details

\section{Crystal data}

\begin{tabular}{ll}
\hline Formula, Z & $\mathrm{KYb}\left(\mathrm{MoO}_{4}\right)_{2}, 4$ \\
Symmetry, space group & Orthorhombic, $\mathrm{P} b c n(60)$ \\
Lattice dimensions $(\AA)$ & $a=5.03950(19), b=18.2821(9), c=7.8634(4)$ \\
Lattice volume $\left(\AA^{3}\right)$ & $\mathrm{V}=724.48(6)$ \\
Crystal dimensions $\left(\mathrm{mm}^{3}\right)$ & $0.29 \times 0.16 \times 0.04$ \\
Calculated density & 4.878 \\
& Data collection \\
\hline Temperature $(\mathrm{K})$ & 298 \\
Radiation, wavelength $(\AA)$ & Mo Ka, 0.71073 \\
$\theta$ range $\left({ }^{\circ}\right)$ & $3.418-32.578$ \\
Limiting indices & $-7 \leq \mathrm{h} \leq 7 ;-26 \leq \mathrm{k} \leq 27 ;-11 \leq 1 \leq 11$ \\
Scan mode & $\omega$ scans \\
Absorption correction; Tmin, Tmax & numerical, $0.10,0.62$ \\
Absorption coefficient $\left(\mathrm{mm}^{-1}\right)$ & 16.79 \\
& Refinement \\
\hline Method & Full-matrix least-squares on $\mathrm{F}^{2}$ \\
Collected / independent reflections & $12880 / 1283\left[\mathrm{R}_{\text {int }}=0.0340\right]$ \\
Data / restraints / parameters & $1283 / 0 / 56$ \\
Final R indices $[\mathrm{I}>2 \sigma(\mathrm{I})]$ & $R 1=0.0557, w R 2=0.1163$ \\
R indices (all data) & $R 1=0.0592, w R 2=0.1173$ \\
Density residuals $\left(\mathrm{e} . \AA^{-3}\right)$ & 3.99 and -3.58 \\
\hline \hline
\end{tabular}

Older reports $[18,28,30]$ gave, for the magnetically concentrated $\mathrm{KYb}\left(\mathrm{MoO}_{4}\right)_{2}$ compound, the orthorhombic cell parameters. A structural type was assigned from powder patterns analogy with $\mathrm{KY}\left(\mathrm{MoO}_{4}\right)_{2}$ structure [17] but no structural refinement is available in the literature. The present study brings the first complete room-temperature structure determination of $\mathrm{KYb}\left(\mathrm{MoO}_{4}\right)_{2}$ double molybdate from single-crystal data. 
Table 2. Atom coordinates $\left(\times 10^{4}\right)$ and equivalent displacement parameters $\left(\AA^{2} \times 10^{3}\right)$ for $\mathrm{KYb}\left(\mathrm{MoO}_{4}\right)_{2}$. $\mathrm{U}_{\mathrm{eq}}$ is defined as one-third of the trace of the orthogonalized $\mathrm{U}_{\mathrm{ij}}$ tensor.

\begin{tabular}{cccccc} 
& Wyckoff position & $\mathbf{x}$ & $\mathbf{y}$ & $\mathbf{z}$ & $\mathbf{U}_{\mathbf{e q}}$ \\
\hline $\mathrm{Yb}$ & $4 c$ & 0 & $49(1)$ & 2500 & $10(1)$ \\
$\mathrm{K}$ & $4 c$ & 0 & $-2276(2)$ & 2500 & $22(1)$ \\
$\mathrm{Mo}$ & $8 d$ & $4776(2)$ & $1003(1)$ & $-144(1)$ & $10(1)$ \\
$\mathrm{O}(1)$ & $8 d$ & $7516(16)$ & $337(5)$ & $67(11)$ & $12(1)$ \\
$\mathrm{O}(2)$ & $8 d$ & $6043(19)$ & $1877(5)$ & $-198(13)$ & $18(2)$ \\
$\mathrm{O}(3)$ & $8 d$ & $2574(17)$ & $926(5)$ & $-1912(11)$ & $13(2)$ \\
$\mathrm{O}(4)$ & $8 d$ & $2658(19)$ & $987(5)$ & $1645(10)$ & $15(2)$ \\
\hline \hline
\end{tabular}

The crystal structure of $\mathrm{KYb}\left(\mathrm{MoO}_{4}\right)_{2}$ drawn with the program Diamond 3.2 [31] is presented in Figure 4, and the main interatomic distances and angles are gathered in Table 3. Looking along the $b$-axis, this structure can be viewed as a multilayered structure with a sequence of $\mathrm{YbMo}_{2} \mathrm{O}_{8}$ complex layers alternated with wavy layers of potassium, which provides the structure with a certain two-dimensional character. The potassium present in the structure as $\mathrm{K}^{+}$cations acts as a link between the $\mathrm{YbMo}_{2} \mathrm{O}_{8}$ layers through bonding ionic interactions. Indeed, the $\mathrm{K}^{+}$cation has a coordination number of 6 with oxygen placed at distances slightly shorter than $2.828 \AA$, the average distance observed for $\mathrm{K}^{+}$ions bonded to oxygen according to an extensive study of bond-length distributions [32]. The oxygen coordination polyhedron around $\mathrm{K}^{+}(2 \times 2.68(1), 2 \times 2.79(1)$, and $2 \times 2.82(1) \AA)$ is a highly distorted octahedron that displays the $C_{2}$ symmetry. 


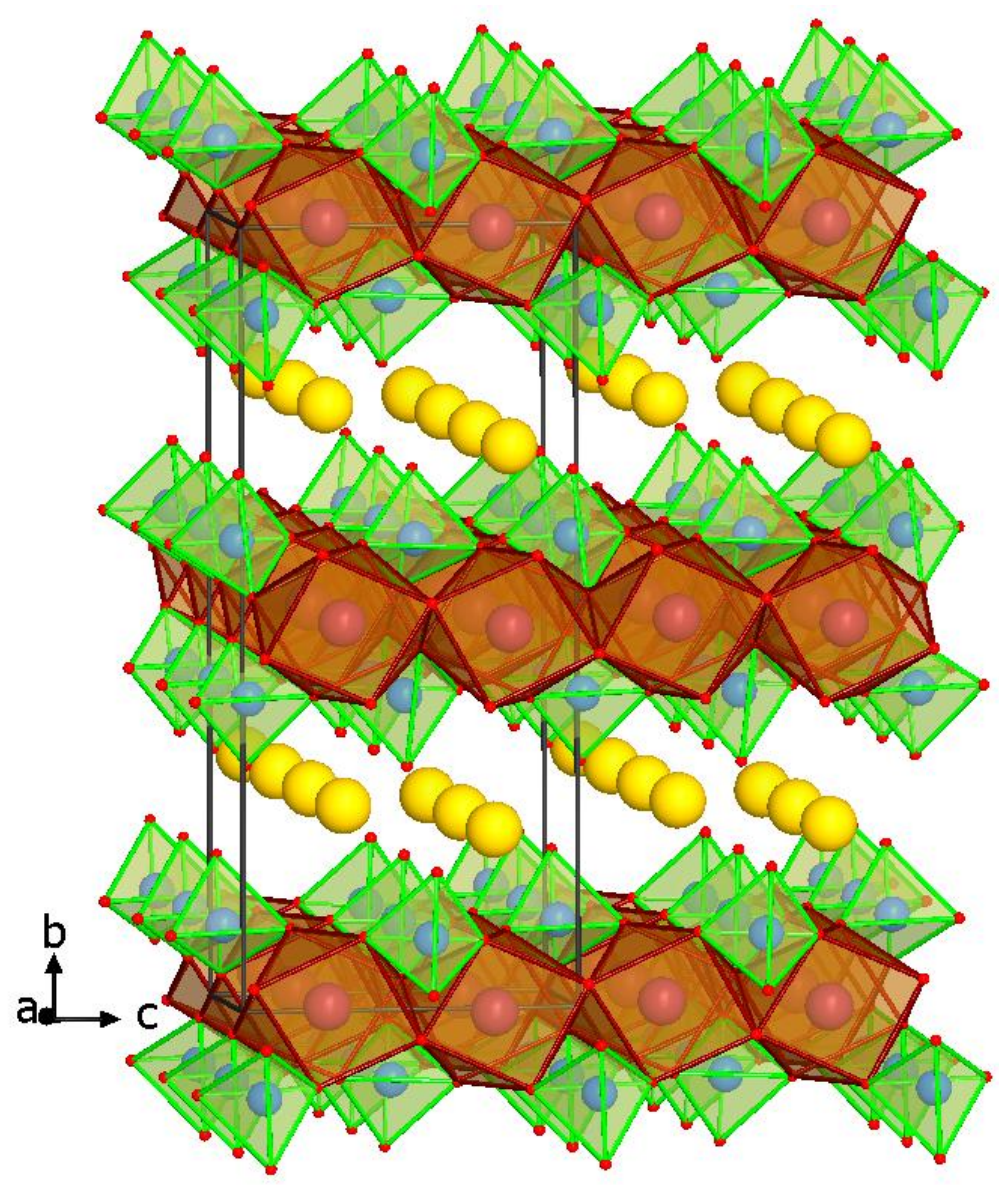

Figure 4. The orthorhombic $\mathrm{Pbcn}$ structure of $\mathrm{KYb}\left(\mathrm{MoO}_{4}\right)_{2}$. Complex layers of $\mathrm{MoO}_{4}$ (green) and $\mathrm{YbO}_{8}$ (brown) polyhedra alternate with $\mathrm{K}^{+}$(yellow) layers

The $\mathrm{YbMo}_{2} \mathrm{O}_{8}$ complex layer can be viewed with a central sheet of $\mathrm{YbO}_{8}$ polyhedra between two sheets of $\mathrm{MoO}_{4}$ polyhedra (Figure 5). The $\mathrm{Yb}^{3+}$ ion sits inside a square antiprism of oxygen at distances from $2.253(9)$ to $2.478(8) \AA$, Table 3 , which is characterized by only a two-fold axis along the $b$ direction. Representation of the $\mathrm{YbMo}_{2} \mathrm{O}_{8}$ complex layer projected on the $a c$ plane (Figure 4) shows that $\mathrm{YbO}_{8}$ square antiprisms share one edge with each of their two alike neighboring units to form chains aligned along the $c$-axis. These $\mathrm{YbO}_{8}$ chains are interconnected through $\mathrm{MoO}_{4}$ distorted tetrahedral units that display the $C 2$ (almost $C 3 v$ ) symmetry. The $\mathrm{MoO}_{4}$ polyhedra are separated from each other since they have no common $\mathrm{O}$, but they share their four $\mathrm{O}$ vertices with four neighboring $\mathrm{YbO}_{8}$ units. With Mo-O distances from 1.722(9) to $1.848(8) \AA$ and O-Mo-O angles between 104.1(4) and 118.9(4) ${ }^{\circ}$, Table 3, the 
$\mathrm{MoO}_{4}$ polyhedra are characterized by strong covalent bonding. Thus, the atoms are covalently bonded within the $\mathrm{YbMo}_{2} \mathrm{O}_{8}$ layers which interact with the potassium layers by ionic bonding in a three-dimensional network. The links between the Mo atoms of successive "layers" occur either through Mo-O-Yb-O-Mo or Mo-O-K-O-Mo paths.

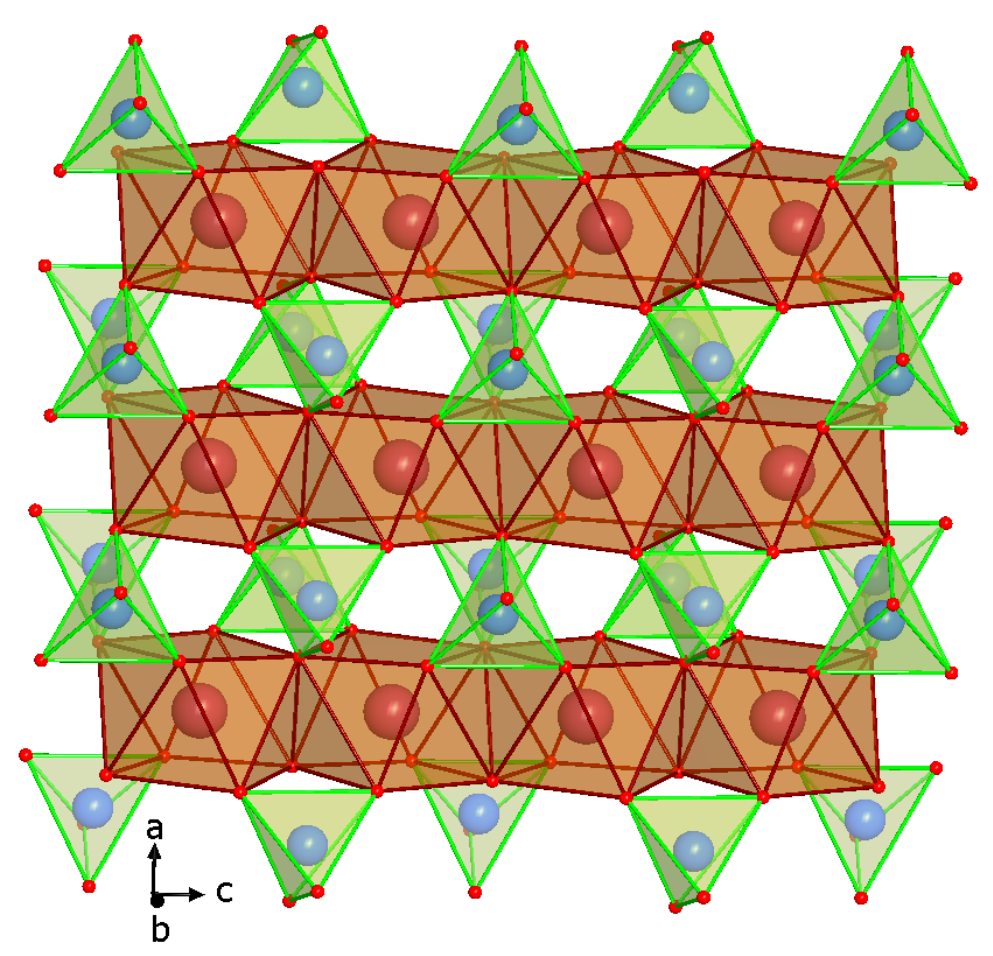

Figure 5. The $\mathrm{YbMo}_{2} \mathrm{O}_{8}$ complex layer (b-projection) built with $\mathrm{YbO}_{8}$ chains (brown) aligned along the $c$-axis and interconnected through $\mathrm{MoO}_{4}$ units (green).

It is interesting to focus on the connection mode of the $\mathrm{YbO}_{8}$ polyhedra and notice the special arrangement of the $\mathrm{MoO}_{4}$ units (Figure 6). The successive Mo sites along the $c$-axis are distant from either 3.712(1) ̊̊ or 4.164(1) Å bringing certain O atoms closer (or further away) from the Mo center. This results in the formation of $\mathrm{Mo}_{2} \mathrm{O}_{8}$ "dimeric-like" units involving two Mo-O(3) interactions of 2.676(8) $\AA$ (dashed orange lines, Figure 6) between the nearest $\mathrm{MoO}_{4}$ units. Longer corresponding Mo-O(4) distances of 3.040(8) ^ (dotted blue lines, Figure 6) are 
found between the dimers. Similar " $\mathrm{Mo}_{2} \mathrm{O}_{8}$ dimers" have been described in the isostructural yttrium double molybdate [33, 34].

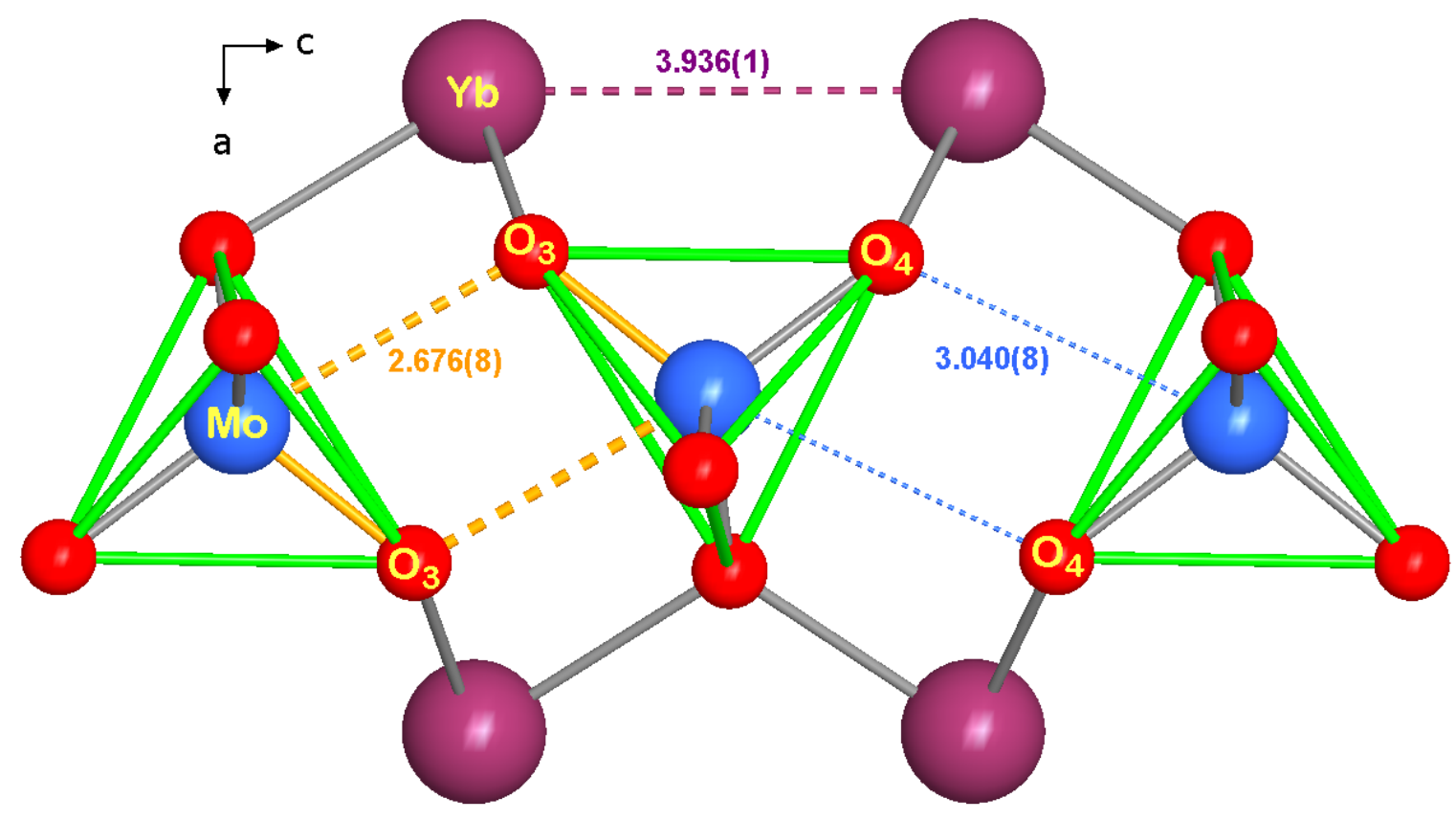

Figure 6. Organization of the $\mathrm{MoO}_{4}$ pseudo-tetrahedral units showing double bridge Mo-O interactions of 2.676(8) $\AA$ (dash orange) within the " $\mathrm{Mo}_{2} \mathrm{O}_{8}$ dimer" and of 3.040(8) $\AA$ (dot blue) between the dimers.

The $\mathrm{K}^{+}$and $\mathrm{Yb}^{3+}$ cations are fully ordered in the orthorhombic crystal $\mathrm{KYb}\left(\mathrm{MoO}_{4}\right)_{2}$ with the $\mathrm{KY}\left(\mathrm{MoO}_{4}\right)_{2}$ structural-type [17]. $\mathrm{KYb}\left(\mathrm{MoO}_{4}\right)_{2}$ double molybdate is isostructural to the $\mathrm{KLn}\left(\mathrm{MoO}_{4}\right)_{2}$ phases with $\mathrm{Ln}=\mathrm{Y}$, Dy, Ho, Er, Tm, Lu [17, 19, 30]. Instead, the double tungstate $\mathrm{KYb}\left(\mathrm{WO}_{4}\right)_{2}$, also with an ordered cation distribution, crystallizes in the monoclinic space group $\mathrm{C} 2 / c\left(C_{2 h}^{6}\right)(\mathrm{Z}=4)$ [35]. Besides, a monoclinic $\mathrm{C} 2 / c$ lattice is also given for the high-pressure form of the $\mathrm{KYb}\left(\mathrm{MoO}_{4}\right)_{2}$ compound which was assigned the structural type $\mathrm{KYW}_{2} \mathrm{O}_{8}$ based on its powder diffraction data [36]. 
Table 3. Selected geometric parameters in $\mathrm{KYb}\left(\mathrm{MoO}_{4}\right)_{2}$

\section{Distances to Yb \\ $\mathrm{Yb}-\mathrm{O}(3)^{\# 1} \quad 2.253(9)$ \\ $\mathrm{Yb}-\mathrm{O}(3)^{\# 2} \quad 2.253(8)$ \\ $\mathrm{Yb}-\mathrm{O}(4) \quad 2.278(9)$ \\ $\mathrm{Yb}-\mathrm{O}(4)^{\# 3} \quad 2.278(9)$ \\ $\mathrm{Yb}-\mathrm{O}(1)^{\# 4} \quad 2.346(8)$ \\ $\mathrm{Yb}-\mathrm{O}(1)^{\# 5} \quad 2.346(8)$ \\ $\mathrm{Yb}-\mathrm{O}(1)^{\# 6} \quad 2.478(8)$ \\ $\mathrm{Yb}-\mathrm{O}(1)^{\# 7} \quad 2.478(8)$}

\section{Distances to Mo}

Mo-O(2) 1.722(9)

Mo-O(4) 1.766(9)

$\mathrm{Mo}-\mathrm{O}(3) \quad 1.785(8)$

$\mathrm{Mo}-\mathrm{O}(1) \quad 1.848(8)$

$\underline{\text { Distances to } \mathrm{K}}$

$\begin{array}{ll}\mathrm{K}-\mathrm{O}(2)^{\# 8} & 2.679(10) \\ \mathrm{K}-\mathrm{O}(2)^{\# 9} & 2.679(10) \\ \mathrm{K}-\mathrm{O}(2)^{\# 6} & 2.790(10) \\ \mathrm{K}-\mathrm{O}(2)^{\# 7} & 2.790(10) \\ \mathrm{K}-\mathrm{O}(3)^{\# 2} & 2.825(10) \\ \mathrm{K}-\mathrm{O}(3)^{\# 1} & 2.825(10)\end{array}$

\section{Angles around $\mathbf{Y b}$}

$\mathrm{O}(3)^{\# 1}-\mathrm{Yb}-\mathrm{O}(3)^{\# 2}$

$75.3(4)$

Angles around Mo

$\mathrm{O}(3)^{\# 1}-\mathrm{Yb}-\mathrm{O}(4) \quad 150.9(3)$

$\mathrm{O}(3)^{\# 2}-\mathrm{Yb}-\mathrm{O}(4)$

$\mathrm{O}(3)^{\# 1}-\mathrm{Yb}-\mathrm{O}(4)^{\# 3}$

$108.5(3)$

$\mathrm{O}(2)-\mathrm{Mo}-\mathrm{O}(4)$

105.0(4)

$108.5(3)$

$\mathrm{O}(2)-\mathrm{Mo}-\mathrm{O}(3)$

106.5(4)

$\mathrm{O}(3)^{\# 2}-\mathrm{Yb}-\mathrm{O}(4)^{\# 3} \quad$ 150.9(3)

$\mathrm{O}(4)-\mathrm{Mo}-\mathrm{O}(3)$

104.1(4)

$\mathrm{O}(4)-\mathrm{Yb}-\mathrm{O}(4)^{\# 3}$

82.3(5)

$\mathrm{O}(2)-\mathrm{Mo}-\mathrm{O}(1)$

109.7(4)

$\mathrm{O}(3)^{\# 1}-\mathrm{Yb}-\mathrm{O}(1)^{\# 4} \quad$ 130.7(3)

$\mathrm{O}(4)-\mathrm{Mo}-\mathrm{O}(1)$

111.7(4)

$\mathrm{O}(3)^{\# 2}-\mathrm{Yb}-\mathrm{O}(1)^{\# 4}$

72.7(3)

$\mathrm{O}(3)-\mathrm{Mo}-\mathrm{O}(1)$

118.9(4)

$\mathrm{O}(4)-\mathrm{Yb}-\mathrm{O}(1)^{\# 4} \quad 76.0(3)$

$\mathrm{O}(4)^{\# 3}-\mathrm{Yb}-\mathrm{O}(1)^{\# 4} \quad 84.5(3)$

$\mathrm{O}(3)^{\# 1}-\mathrm{Yb}-\mathrm{O}(1)^{\# 5} \quad 72.7(3)$

Angles around K

$\mathrm{O}(3)^{\# 2}-\mathrm{Yb}-\mathrm{O}(1)^{\# 5} \quad 130.7(3)$

$\mathrm{O}(4)-\mathrm{Yb}-\mathrm{O}(1)^{\# 5} \quad$ 84.5(3)

$\mathrm{O}(2)^{\# 8}-\mathrm{K}-\mathrm{O}(2)^{\# 9}$

109.4(4)

$\mathrm{O}(4)^{\# 3}-\mathrm{Yb}-\mathrm{O}(1)^{\# 5} \quad 76.0(3)$

$\mathrm{O}(2)^{\# 8}-\mathrm{K}-\mathrm{O}(2)^{\# 6}$

77.1(2)

$\mathrm{O}(1)^{\# 4}-\mathrm{Yb}-\mathrm{O}(1)^{\# 5} \quad 154.1(4)$

$\mathrm{O}(2)^{\# 9}-\mathrm{K}-\mathrm{O}(2)^{\# 6}$

121.64(13)

$\mathrm{O}(3)^{\# 1}-\mathrm{Yb}-\mathrm{O}(1)^{\# 6} \quad$ 84.2(3)

$\mathrm{O}(2)^{\# 8}-\mathrm{K}-\mathrm{O}(2)^{\# 7}$

121.64(13)

$\mathrm{O}(3)^{\# 2}-\mathrm{Yb}-\mathrm{O}(1)^{\# 6} \quad$ 69.6(3)

$\mathrm{O}(2)^{\# 9}-\mathrm{K}-\mathrm{O}(2)^{\# 7}$

77.1(2)

$\mathrm{O}(4)-\mathrm{Yb}-\mathrm{O}(1)^{\# 6}$

71.2(3)

$\mathrm{O}(2)^{\# 6}-\mathrm{K}-\mathrm{O}(2)^{\# 7}$

149.7(4)

$\mathrm{O}(4)^{\# 3}-\mathrm{Yb}-\mathrm{O}(1)^{\# 6} \quad 138.8(3)$

$\mathrm{O}(2)^{\# 8}-\mathrm{K}-\mathrm{O}(3)^{\# 2}$

136.4(3)

$\mathrm{O}(1)^{\# 4}-\mathrm{Yb}-\mathrm{O}(1)^{\# 6}$

117.3(3)

$\mathrm{O}(2)^{\# 9}-\mathrm{K}-\mathrm{O}(3)^{\# 2}$

106.6(3)

$\mathrm{O}(1)^{\# 5}-\mathrm{Yb}-\mathrm{O}(1)^{\# 6}$

70.7(3)

$\mathrm{O}(2)^{\# 6}-\mathrm{K}-\mathrm{O}(3)^{\# 2}$

63.3(3)

$\mathrm{O}(3)^{\# 1}-\mathrm{Yb}-\mathrm{O}(1)^{\# 7} \quad 69.6(3)$

$\mathrm{O}(2)^{\# 7}-\mathrm{K}-\mathrm{O}(3)^{\# 2}$

89.7(3)

$\mathrm{O}(3)^{\# 2}-\mathrm{Yb}-\mathrm{O}(1)^{\# 7}$

84.2(3)

$\mathrm{O}(2)^{\# 8}-\mathrm{K}-\mathrm{O}(3)^{\# 1}$

106.6(3)

$\mathrm{O}(4)-\mathrm{Yb}-\mathrm{O}(1)^{\# 7} \quad 138.8(3)$

$\mathrm{O}(2)^{\# 9}-\mathrm{K}-\mathrm{O}(3)^{\# 1}$

136.4(3)

$\mathrm{O}(4) \# 3-\mathrm{Yb}-\mathrm{O}(1)^{\# 7} \quad 71.2(3)$

$\mathrm{O}(2)^{\# 6}-\mathrm{K}-\mathrm{O}(3)^{\# 1}$

89.7(3)

$\mathrm{O}(1) \# 4-\mathrm{Yb}-\mathrm{O}(1)^{\# 7} \quad 70.7(3)$

$\mathrm{O}(2)^{\# 7}-\mathrm{K}-\mathrm{O}(3)^{\# 1}$

63.3(3)

$\mathrm{O}(1) \# 5-\mathrm{Yb}-\mathrm{O}(1)^{\# 7}$

117.3(3)

$\mathrm{O}(3)^{\# 2}-\mathrm{K}-\mathrm{O}(3)^{\# 1}$

58.3(3)

$\mathrm{O}(1) \# 6-\mathrm{Yb}-\mathrm{O}(1)^{\# 7} \quad$ 146.9(4)

Symmetry transformations to generate equivalent atoms: ${ }^{\# 1}-\mathrm{x},-\mathrm{y},-\mathrm{z} ;{ }^{\# 2} \mathrm{x},-\mathrm{y}, \mathrm{z}+1 / 2 ;{ }^{\# 3}-\mathrm{x}, \mathrm{y},-\mathrm{z}+1 / 2 ;{ }^{\# 4}-$ $\mathrm{x}+1, \mathrm{y},-\mathrm{z}+1 / 2 ;{ }^{\# 5} \mathrm{x}-1, \mathrm{y}, \mathrm{z} ;{ }^{\# 6}-\mathrm{x}+1,-\mathrm{y},-\mathrm{z} ;{ }^{\# 7} \mathrm{x}-1,-\mathrm{y}, \mathrm{z}+1 / 2 ;{ }^{\# 8}-\mathrm{x}+1 / 2, \mathrm{y}-1 / 2, \mathrm{z} ;{ }^{\# 9} \mathrm{x}-1 / 2, \mathrm{y}-1 / 2,-\mathrm{z}+1 / 2$ 
The free $\left[\mathrm{MoO}_{4}\right]^{2-}$ ion with $\mathrm{Td}$ point symmetry is characterized by four internal fundamental vibration modes $v_{1}\left(\mathrm{~A}_{1}\right), v_{2}(\mathrm{E}), v_{3}\left(\mathrm{~F}_{2}\right)$, and $v_{4}\left(\mathrm{~F}_{2}\right)$, one free rotation mode and one translation mode $\left(\mathrm{F}_{2}\right)[35,36]$. As the $\mathrm{MoO}_{4}$ units are slightly distorted tetrahedra in the crystal structure of $\mathrm{KYb}\left(\mathrm{MoO}_{4}\right)_{2}$, their local symmetry is lowered. It thus results in the splitting of all the degenerate vibrations due to the crystal field (CF) effect [37, 38].

Intense bands are visible in the Raman spectrum of $\mathrm{KYb}\left(\mathrm{MoO}_{4}\right)_{2}$ registered under ambient conditions for a selected single crystal, Figure 7. This spectrum presents a strong similarity with that of $\mathrm{KY}\left(\mathrm{MoO}_{4}\right)_{2}$, in agreement with the isostructural nature of these two orthorhombic compounds with a "polymeric nature" due to the presence of $\left[\mathrm{LnO}_{8}\right]_{\mathrm{n}}$ chains $[33,39]$. It should be mentioned that no Raman band is observed for $\mathrm{KYb}\left(\mathrm{MoO}_{4}\right)_{2}$ in the frequency range over $1000 \mathrm{~cm}^{-1}$. The maximal phonon frequency of $946 \mathrm{~cm}^{-1}$ corresponds to rather low energy, indicating that $\mathrm{KYb}\left(\mathrm{MoO}_{4}\right)_{2}$ material could be a suitable host for good upconverting luminescence properties [40].

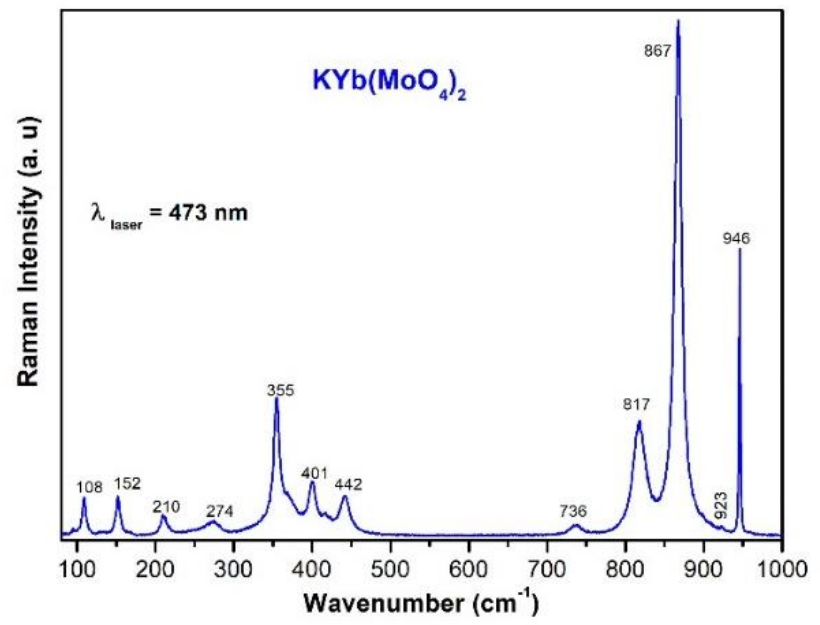

Figure 7. Unpolarized Raman spectrum registered at room temperature.

According to previous papers on vibrational studies of molybdates, the bands above $700 \mathrm{~cm}^{-1}$ are assigned to internal symmetric and antisymmetric stretching modes of the $\mathrm{O}$ atoms of the tetrahedral molybdate anions $\left(\mathrm{MoO}_{4}\right)^{2-}[33,39]$. Internal symmetric and asymmetric O-Mo- 
$\mathrm{O}$ bending vibration modes of the $\left(\mathrm{MoO}_{4}\right)^{2-}$ units are observed in the $300-450 \mathrm{~cm}^{-1}$ frequency region [33]. The weak band observed at $736 \mathrm{~cm}^{-1}$ could be assigned to the stretching vibrations of the double-bridge in the " $\mathrm{Mo}_{2} \mathrm{O}_{8}$ dimers" (Figure 5) as already reported for the yttrium double molybdate $[33,34]$. Finally, the bands below $300 \mathrm{~cm}^{-1}$ may originate from translational motions of $\mathrm{K}^{+}, \mathrm{Yb}^{3+},\left(\mathrm{MoO}_{4}\right)^{2-}$ ions, and lattice rotational modes as already reported [33].

\subsection{Magnetic properties}

The magnetic properties of the double molybdate $\mathrm{KYb}\left(\mathrm{MoO}_{4}\right)_{2}$ have been characterized by the determination of its magnetic susceptibility. The magnetization was measured for a sample placed in a constant magnetic field $H$ of $0.5 \mathrm{~T}$ at temperatures ranging from 1.8 to $300 \mathrm{~K}$. The magnetization depends on the size and the respective alignment of the dipolar atomic moments. The electronic configuration of the paramagnetic $\mathrm{Yb}^{3+}$ isolated ion is $[\mathrm{Xe}]$ $4 f^{13}$ with $[X e]=2 s^{2} 2 p^{6} 3 s^{2} 3 p^{6} 3 d^{10} 4 s^{2} 4 p^{6} 4 d^{10}$, which yields the spectral term ${ }^{2} \mathrm{~F}_{7 / 2}$ as the ground state, and the effective magnetic moment $\mu_{\mathrm{eff}}$ of $\mathrm{Yb}^{3+}$ is equal to $4.54 \mu_{\mathrm{B}}$.

No variation was observed between the data collected after cooling the sample in a magnetic field (FC) and the data collected after cooling in a zero field (ZFC). The magnetic susceptibility was corrected from the diamagnetic contribution of $\mathrm{KYb}\left(\mathrm{MoO}_{4}\right)_{2}$ estimated to be $\chi_{\text {dia }}=-2.66 \cdot 10^{-4} \mathrm{emu} / \mathrm{mol}$.

Figure 8(a) shows that the Yb molar dc magnetic susceptibility $\chi$ of a $381 \mathrm{mg}$ sample of asgrown $\mathrm{KYb}\left(\mathrm{MoO}_{4}\right)_{2}$ crystals, measured in a constant magnetic field $H$ of $5000 \mathrm{Oe}$, is temperature-dependent. On cooling up to $40 \mathrm{~K}$, the susceptibility curve shows a continuous and slow increase. In the low-temperature range $1.8-40 \mathrm{~K}$, the magnetic susceptibility increases sharply. 

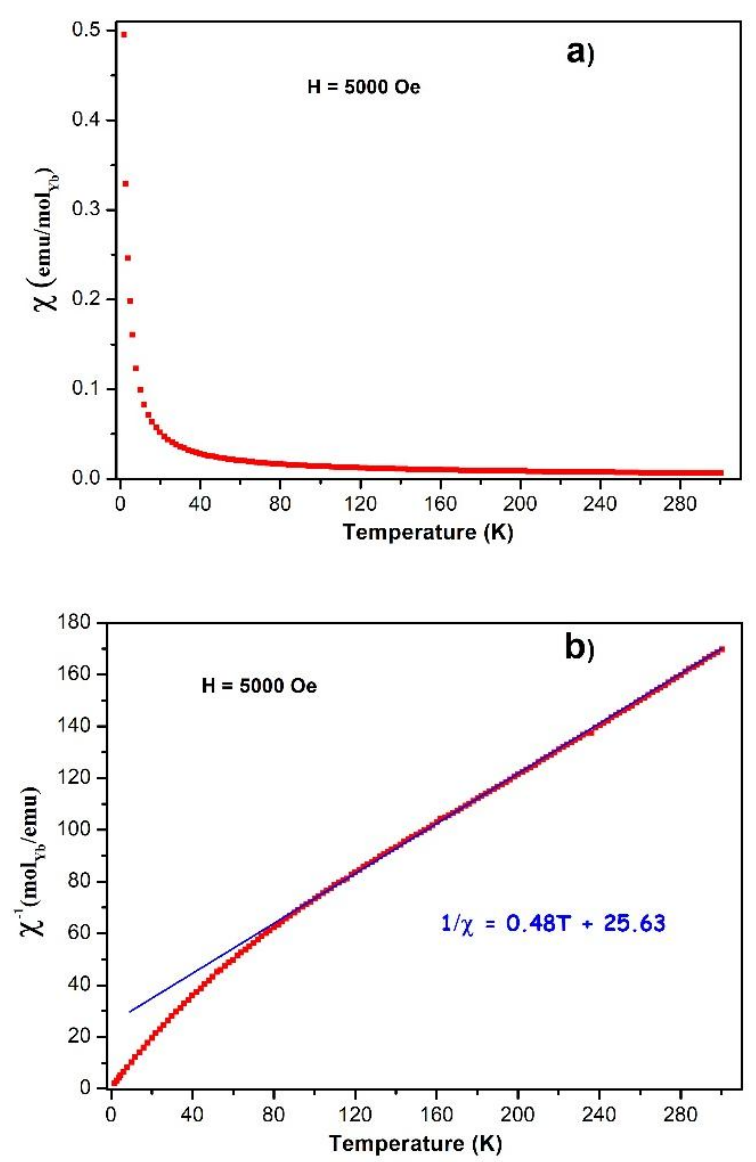

Figure 8. Magnetic (a) and inverse (b) susceptibility $\chi$ of $\mathrm{KYb}\left(\mathrm{MoO}_{4}\right)_{2}$ in a constant $H$ field as a function of the temperature, with a Curie-Weiss fit (blue line) of the high-temperature data.

For the high-temperature range, we notice a linear behavior of the inverse magnetic susceptibility $\chi^{-1}$ from $300 \mathrm{~K}$ down to $80 \mathrm{~K}$, Figure $8(\mathrm{~b})$. The data obey a Curie-Weiss law $\chi_{\mathrm{mol}}=C /\left(T-\theta_{\mathrm{p}}\right)$ with the least-squares parameters $C=2.08(1)$ emu.mol ${ }^{-1}$ (Curie constant) and $\theta_{\mathrm{p}}=-52 \mathrm{~K}$ (paramagnetic Curie-Weiss temperature). The experimental effective magnetic moment $\mu_{\text {eff }}$ of $4.1(1) \mu_{\mathrm{B}} / \mathrm{Yb}$, calculated for $\mathrm{KYb}\left(\mathrm{MoO}_{4}\right)_{2}$ from the Curie constant $\left(\mu_{\mathrm{eff}}=(8 \times\right.$ C) ${ }^{1 / 2}$ ), is in good agreement with the $\mu_{\text {eff }}$ value expected for the $\mathrm{Yb}^{3+}$ free-ion. This result underlines the weak effect, in the 80-300 K domain, of the crystal field (CF) environment on the magnetic properties of the $f$ electrons in the Yb-based double molybdate under study. 
A very large negative value of $\theta_{\mathrm{p}}$ has already been reported for Yb-based oxides [40, 41]. Such "exceptional comportment" of $\mathrm{Yb}^{3+}$ could suggest an antiferromagnetic coupling between the magnetic moments. In the orthorhombic structure of $\mathrm{KYb}\left(\mathrm{MoO}_{4}\right)_{2}$, the $\mathrm{Yb}$ sites are separated by $3.9358(2) \AA$, a rather short distance for $\mathrm{Yb}$... Yb interactions, which could lead to an antiferromagnetic coupling between the $\mathrm{Yb}^{3+}$ cations, Figure 5. However, this antiferromagnetic coupling should be weak, and thus, the large negative $\theta_{\mathrm{p}}$ value may have other origins. Alternative explanations could be thought in term of isolated $\mathrm{Yb}^{3+}$ centers in the lattice as already described for $\operatorname{Sr}_{2} \mathrm{YbMO}_{6}(M=\mathrm{Nb}, \mathrm{Ta}, \mathrm{Sb})$ materials [40], and of the crystalline electric field effect on the ${ }^{2} \mathrm{~F}_{7 / 2}$ ground state of $\mathrm{Yb}^{3+}$ ions as already reported [15, 40-43]. The arrangement of oxygen around the $\mathrm{Yb}^{3+}$ ions would give rise to a splitting of the ${ }^{2} \mathrm{~F}_{7 / 2}$ ground state at low temperatures.

The field-dependent $\mathrm{M}-H$ curves plotted for $\mathrm{KYb}\left(\mathrm{MoO}_{4}\right)_{2}$ at different temperatures ranging from $1.8 \mathrm{~K}$ up to $300 \mathrm{~K}$ are given in Figure 9. Several magnetic regimes are observed. The magnetization $\mathrm{M}$ measured at $\mathrm{T}=1.8 \mathrm{~K}$ displays a large field dependence with a saturation zone starting from $H=40 \mathrm{kOe}$ up to the highest applied magnetic field $H=50 \mathrm{kOe}$. The saturation reaches $1.8 \mu_{\mathrm{B}} / \mathrm{Yb}$ at $5 \mathrm{~T}$. At $1.8 \mathrm{~K}$, the magnetic alignment becomes geometrically frustrated.

At $\mathrm{T}=300 \mathrm{~K}$, the magnetization is a linear function of the field $H$ within the whole magnetic field range investigated in accordance with a paramagnetic behavior.

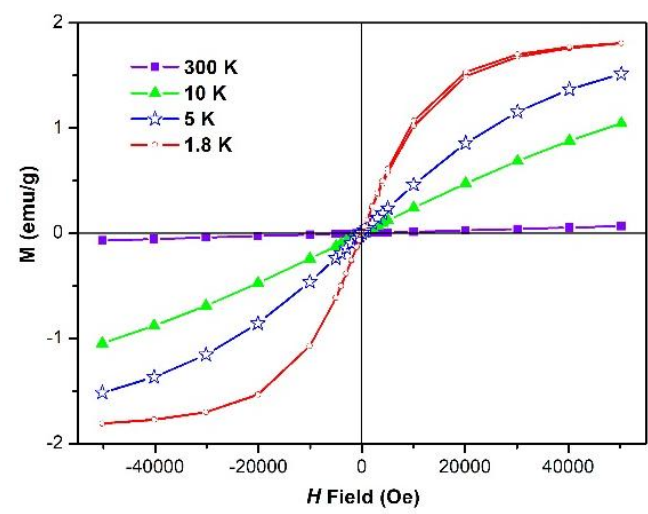


Figure 9. $\mathrm{M}-\mathrm{H}$ curves recorded at different temperatures for crushed $\mathrm{KYb}\left(\mathrm{MoO}_{4}\right)_{2}$ crystals.

\section{Conclusion}

$\mathrm{KYb}\left(\mathrm{MoO}_{4}\right)_{2}$ double molybdate was obtained for the first time as transparent and colorless single crystals, using a high-temperature solution technique. The flux-grown material crystallizes in the orthorhombic symmetry with the $\mathrm{Mo}^{\mathrm{VI}}$ valence state and displays an ordered distribution of the $\mathrm{K}^{+}$and $\mathrm{Yb}^{3+}$ cations, both on $C_{2}$ symmetry positions. The structural type $\mathrm{KY}\left(\mathrm{MoO}_{4}\right)_{2}$ was assigned based on single-crystal structure determination. The existence of " $\mathrm{Mo}_{2} \mathrm{O}_{8}$ dimers" was confirmed by the presence of the $736 \mathrm{~cm}^{-1}$ Raman band assigned to the stretching vibrations of Mo-O double-bridge interactions. Magnetic properties of $\mathrm{KYb}\left(\mathrm{MoO}_{4}\right)_{2}$ have been investigated from 1.8 to $300 \mathrm{~K}$. The temperature-dependent magnetic susceptibility follows a Curie-Weiss law from 80 to $300 \mathrm{~K}$, with a very large negative paramagnetic constant $\theta \mathrm{p}$ of $-52 \mathrm{~K}$. Such exceptional comportment of $\mathrm{Yb}^{3+}$ would suggest an antiferromagnetic spin-order coupling between the $\mathrm{Yb}^{3+}$ ions. A magnetic neutron diffraction study would help to clarify the existence of a potential ordered magnetic state in $\mathrm{KYb}\left(\mathrm{MoO}_{4}\right)_{2}$.

\section{Acknowledgments}

Raman, magnetic, and X-ray diffraction experiments were done at the Platform of Analysis and Characterization of the Pôle Chimie Balard in Montpellier, France.

\section{Funding source}

Funding for this research was provided by the Ministry of Higher Education, Scientific Research and Innovation in France, and the French National Center of Scientific Research (CNRS). 


\section{References}

[1] Double Molybdates and Tungstates of the Rare Earth and Alkali Metals A.A. Maier, M.V. Provotorov, V.A. Balashov

Russian Chemical Reviews, 42 (10) (1973) 822-833.

[2] Polymorphism of the double molybdates and tungstates of mono- and trivalent metals with the composition $\left.\mathrm{M}^{+} \mathrm{R}^{3+(} \mathrm{EO}_{4}\right)_{2}$.

P.V. Klevtsov, R.F. Klevtsova

J. Struct. Chem. 18 (1977) 339-355.

https://doi.org/10.1007/BF00753083

[3] Flux growth crystals of $\mathrm{RKMo}_{2} \mathrm{O}_{8}, \mathrm{R}_{2} \mathrm{MoO}_{6}$, and $\mathrm{R}_{6} \mathrm{MoO}_{12}$ in the system $\mathrm{R}_{2} \mathrm{O}_{3}-\mathrm{K}_{2} \mathrm{O}-\mathrm{MoO}_{3}$

B. M. Wanklyn, F.R. Wondre

J. Crystal Growth, 43 (1978) 93-100.

[4] The formation and structural parameters of new double molybdates $\mathrm{RbLn}\left(\mathrm{MoO}_{4}\right)_{2}(\mathrm{Ln}=\mathrm{Pr}, \mathrm{Nd}$, $\mathrm{Sm}, \mathrm{Eu})$

O.D. Chimitova, V.V Atuchin, B.G. Bazarov, M.S. Molokeev, Z.G. Bazarova

Izv. Akad. Nauk. Khim. Nauki (Engl. Transl.) 5(2) (1984) 68-71.

[5] Synthesis, characterization, high-temperature phase transition, and electrical properties of solid solution $\mathrm{AgScMo}_{2} \mathrm{O}_{8}$.

Q. B. Bo, C. L. Chen, Y. X. Li, Z. X. Sun, G .X. Sun, J. Meng

J. Materials Science Materials in Electronics 17(10) (2006) 825-830

DOI: 10.1007/s10854-006-0029-9.

[6] A review of phase transitions in RbIn-molybdate

M. B. Zapart, W. Zapart

Nukleonika, 58 (2013) 365-370.

[7] Synthesis, crystal structure, phonon, magnetic and electrical properties of new molybdate $\mathrm{Na}_{2} \mathrm{Mn}_{2}\left(\mathrm{MoO}_{4}\right)_{3}$

I. Jendoubia, M. Ptakb, A. Pikulb, J. Chmielowiecb, A. Ciupab, M. Mączkab, M.Faouzi Zid

J. Solid State Chem., 277 (2019) 738-750.

[8] Growth and spectroscopy of orthorhombic $\mathrm{Yb}: \mathrm{KY}\left(\mathrm{MoO}_{4}\right)_{2}$ laser crystal with a layered structure.

A. Volokitina, P. Loiko, J-M. Serres, X. Mateos, N. Kuleshov, V. Trifonov, A. Pavlyuk

J. Phys. : Conf. Series, 1410 (2019) 012149

[9] The optical spectroscopy of lanthanides $\mathrm{R}^{3+}$ in $\mathrm{ABi}\left(\mathrm{XO}_{4}\right)_{2}(\mathrm{~A}=\mathrm{Li}, \mathrm{Na} ; \mathrm{X}=\mathrm{Mo}, \mathrm{X})$ and $\mathrm{LiYb}\left(\mathrm{MoO}_{4}\right)_{2}$ multifunctional single crystals: Relationship with the structural local disorder.

C. Cascales, A. Méndez Blas, M. Rico, V. Volkov, C. Zaldo

Optical Materials 27 (2005) 1672-1680

Doi :10.1016/j.optmat.2004.11.051

[10] Double tungstate and molybdate crystals for laser and nonlinear optical applications

E.V. Zharikov, C. Zaldo, F. Diaz

MRS bulletin 34 (2009) 271-275.

[11] AC impedance analysis of $\mathrm{LaLiMo}_{2} \mathrm{O}_{8}$ electroceramics

S. Brahma, R.N.P. Choudhary, A. K. Thakur

Physica B: Condensed Matter 355 (2005) 188-201. 
[12] Raman laser based on a $\mathrm{KGd}\left(\mathrm{WO}_{4}\right)_{2}$ crystal: generation of stokes components in the 1.7-1.8 $\mu \mathrm{m}$ range

V. I Dashkevich, V. A. Orlovich,

J. Applied Spectroscopy 79 (2013) 975-981.

[13] Magnetostriction of rare-earth double tungstate

M.T. Borowiec, I. Krynetski, V. P. Dyakonov, A. Nabialek, T. Zayarnyuk, H. Szymczak

New J. Phys. 8 (2006) 124-1 - 124-9.

[14] Determination of the $g$-factors measured by EPR based on theoretical crystal field and superposition model analyses for lanthanide-based magnetically concentrated crystals - case study: double tungstates and molybdates

H.-G. Liu, C. Rudowicz, P. Gnutek

Philosophical Magazine 99 (2019) 224-246.

DOI: $10.1080 / 14786435.2018 .1532124$

[15] The magnetic, spectroscopic, and thermal properties of $\mathrm{KDyMo}_{2} \mathrm{O}_{8}$.

A. H. Cooke, M. M. Davidson, N. J. England, M. J. M. Leask, J. B. Lowry, A. C. Tropper, M. R. Wells

Journal of Physics C: Solid State Physics, 9(20) (1976) L573- L578.

[16] A Six-Coordinate Ytterbium Complex Exhibiting Easy-Plane Anisotropy and Field-Induced Single-Ion Magnet Behavior

Jun-Li. Liu, K. Yuan, Ji-D. Leng, L. Ungur, W. Wernsdorfer, Fu-Sheng Guo, L. F. Chibotaru, Ming-L. Tong

Inorg. Chem. 51(15) (2012) 8538-8544.

DOI: $10.1021 /$ ic $301115 b$

[17] X-ray diffraction study of double molybdates $\mathrm{KY}\left[\mathrm{MoO}_{4}\right]_{2}$

R.F. Klevtsova, S.V. Borisov

Dokl. Akad. Nauk SSSR, 177(6) (1967) 1333-1336

[18] X-ray and thermographic studies of the double molybdates, $\mathrm{KLn}\left[\mathrm{MoO}_{4}\right]_{2}$

P.V. Klevtsov, L.P. Kozeeva

Inorg. Mater. 4 (1968) 1213-1215.

[19] Polarized i.r. and Raman spectra of orthorhombic $\mathrm{KLn}\left(\mathrm{MoO}_{4}\right)_{2}$ crystals $(\mathrm{Ln}=\mathrm{Y}$, Dy, Ho, Er, Tm, $\mathrm{Yb}, \mathrm{Lu})$

J. Hanuza, L. Macalik

Spectrochemica Acta 38A (1982) 61-72.

[20] Interaction of electronic excitations of $\mathrm{Tm}^{3+}$ ions with acoustic vibrations in $\mathrm{KTm}\left(\mathrm{MoO}_{4}\right)_{2}$

D.D. Kamenskyi, S. Poperezhai, P. Gogoi, H. Engelkamp, J. C. Maan, J. Wosnitza, V. Kut'ko

Phys. Rev. B 89 (2014) 014410

DOI : 10.1103/PhysRevB.89.014410

[21] Electron paramagnetic resonance studies of $\mathrm{KYb}\left(\mathrm{MoO}_{4}\right)_{2}$

K.G. Dergachev, M.I. Kobets, E.N. Khatsko

Physica B 388(1-2)

[22] Single-crystal growth, structure, and optical properties of a new non-centrosymmetric germanate, $\mathrm{RbSbGe}_{3} \mathrm{O}_{9}$

P. Armand, M. Tillard, A. Haidoux, L. Daenens.

J. Solid State Chem. 286 (2020) 121290 
DOI : 10.1016/j.jssc.2020.121290

[23] Crystallographic Computing System JANA2006: General features

Petricek, V., Dusek, M., Palatinus, L.

Z. Kristallogr. 229(5) (2014) 345-352.

DOI : $10.1515 /$ zkri-2014-1737

[24] CrysAlis'Red' 171 software package,

Oxford Diffraction Ltd, Abingdon, United Kingdom, (2004).

[25] Crystal structure refinement with SHELXL

G. M. Sheldrick

Acta Crystallogr. C71 (2015) 3-8

DOI : $10.1107 / \mathrm{S} 2053229614024218$

[26] SHELXT - Integrated space-group and crystal-structure determination

G. M. Sheldrick

Acta Crystallogr. A71 (2015) 3-8

DOI : $10.1107 /$ S2053273314026370

[27] The joint Committee on Powder Diffraction Standards Card Nº0-27-0416.

[28] The joint Committee on Powder Diffraction Standards Card Nº0-050-1762.

[29] http://www.ccdc.cam.ac.uk/conts/retrieving.html (or from the CCDC, 12 Union Road, Cambridge CB2 1EZ, UK; Fax: +44 1223 336033; E-mail: deposit@ccdc.cam.ac.uk).

[30] Etude cristallochimique de quelques molybdates et tungstates de métaux trivalents

P.V. Klevtsov

Bull. Soc. Fr. Minéral. Cristallogr. 92 (1969) 352-359.

[31] Diamond - Crystal and Molecular Structure Visualization

Crystal Impact

Dr. H. Putz \& Dr. K. Brandenburg GbR, Kreuzherrenstr. 102, 53227 Bonn, Germany http://www.crystalimpact.com/diamond

[32] Bond-length distributions for ions bonded to oxygen: alkali and alkaline-earth metals

O.C. Gagné, F.C. Hawthorne

Acta Crystallogr. (2016) B72, 602-625

[10.1107/S2052520616008507]

[33] Polarized Raman and Infrared Spectra of a Multilayer $\mathrm{KY}\left(\mathrm{MoO}_{4}\right)_{2}$ Crystal

J. Hanuza, L. Labuda

J. Raman Spectroscopy 11(4) (1981) 231-237.

[34] Vibrational characteristics of the single-bridge MoOMo and double-bridge MoO2Mo intermolecular interactions-polarized infrared and Raman spectra of monoclinic $\mathrm{KBi}\left(\mathrm{MoO}_{4}\right)_{2}$ single crystal.

J. Hanuza, M. Maczka, J.H. van der Maasb

Vibrational Spectroscopy 8(3) (1995) 417-423.

DOI: $10.1016 / 0924-2031(94) 00076-S$

[35] EPR and optical properties of $\mathrm{KYb}\left(\mathrm{WO}_{4}\right)_{2}$ and $\mathrm{KTb}_{0.2} \mathrm{Yb}_{0.8}\left(\mathrm{WO}_{4}\right)_{2}$ single crystals 
S M. Kaczmarek, L. Macalik, H. Fuks, G. Leniec, T. Skibinski, J. Hanuza

Cent. Eur. J. Phys. 10(2) (2012) 492-499

DOI: $10.2478 / \mathrm{s} 11534-011-0103-7$

[36] Potassium rare-earth element double molybdates,

B.M. Sokolovskii, A.A. Evdokimov, V.K. Trunov

Russ. J. Inorg. Chem. (1977) 22, 816-819

[37] Spontaneous Raman spectroscopy of tungstate and molybdate crystals for Raman lasers

T.T. Basiev, A.A. Sobol, Yu.K. Voronko, P.G. Zverev

Optical Materials 15 (2000) 205-216.

[38] Phonon characteristics and dielectric properties of $\mathrm{BaMoO}_{4}$ ceramic

En-Cai Xiao, Jianzhu Li, Jing Wang, Chao Xing, Mei Guo, Hengyang Qiao, Qing Wang, Ze-Ming Qi, Gang Dou, Feng Shi.

Journal of Materiomics 4(4) (2018) 383-389.

DOI : 10.1016/j.jmat.2018.08.004

[39] Pressure- Induced Phase Transitions in $\mathrm{KDy}\left(\mathrm{MoO}_{4}\right)_{2}$ and $\mathrm{KY}\left(\mathrm{MoO}_{4}\right)_{2}$ : a High- Pressure Raman Study

A. Jayaraman S. K. Sharma S. Y. Wang S. R. Shieh L. C. Ming S.- W. Cheong

J. Raman Spectroscopy 27(6) (1996) 485-490.

[40] Structural and magnetic study of $\mathrm{Yb}^{3+}$ in the perovskites $\mathrm{Sr}_{2} \mathrm{YbMO}_{6}(\mathrm{M}=\mathrm{Nb}, \mathrm{Ta}, \mathrm{Sb})$

F. C. Coomer, J. Campbell, N. Giordano, O. M.Collins, E. J.Cussen

Journal of Solid State Chemistry 221 (2015) 411- 417.

DOI: $10.1016 / j . j s s c .2014 .10 .025$.

[41] Crystal growth, crystal structure, and anisotropic magnetic properties of $\mathrm{KBaR}\left(\mathrm{BO}_{3}\right)_{2}(\mathrm{R}=\mathrm{Y}$, $\mathrm{Gd}$, $\mathrm{Tb}, \mathrm{Dy}, \mathrm{Ho}, \mathrm{Tm}, \mathrm{Yb}$, and $\mathrm{Lu}$ ) triangular lattice materials

S. Guo, T. Kong, F. Alex Cevallos, K. Stolze, R. J. Cava

Journal of Magnetism and Magnetic Materials 472 (2019) 104-110

[42] Mutual energy transfer luminescent properties in novel $\mathrm{CsGd}\left(\mathrm{MoO}_{4}\right)_{2}: \mathrm{Yb}^{3+}, \mathrm{Er}^{3+} / \mathrm{Ho}^{3+}$ phosphors for solid-state lighting and solar cells.

K. Li, R. van Deun

Phys.Chem.Chem.Phys. 21 (2019) 4746- 4754.

[43] Low-temperature phase transition in $\mathrm{KDy}\left(\mathrm{MoO}_{4}\right)_{2}$ produced by the cooperative Jahn-Teller effect. A.I. Zvyagin, T.S. Stetsenko, V.G. Yurko, R.A. Vaishnoras JETP-Letters 17 (1973) 135-137. 